\title{
New Trypetheliaceae from northern and southern Atlantic rainforests in Brazil
}

\author{
André APTROOT, Cléverton de Oliveira MENDONÇA, \\ Danyelly Santos ANDRADE, Jeanne dos Reis SILVA, \\ Suzana Maria de Azevedo MARTINS, Emerson GUMBOSKI, \\ Carlos Augusto Vidigal FRAGA JÚNIOR and Marcela Eugenia da Silva CÁCERES
}

\begin{abstract}
The following 16 new species of Trypetheliaceae are described from Brazil: Astrothelium aeneoides Aptroot, differing from $A$. aeneum by the absence of pigment on the thallus, but medulla of pseudostroma $\mathrm{K}+$ blood red and ascospores 3-septate, lumina diamond-shaped; $A$. curvatum Aptroot $\&$ M. Cáceres with immersed pyriform ascomata with lateral ostioles and bent, muriform ascospores, 74-90 × 25-34 $\mu \mathrm{m} ;$ A. globosum Aptroot \& M. Cáceres with immersed ascomata, thallus consisting of nearly globose warts and ascospores 3-septate, 35-40 $\times 11-13 \mu \mathrm{m} ; A$. graphicum Aptroot \& S. M. A. Martins with an extended, reticulate pseudostroma, which is lower than the slightly bullate thallus, orange pruina on the thallus and pseudostroma and ascospores muriform, $60-66 \times 12-16 \mu \mathrm{m}$; A. longisporum Aptroot, J. R. Silva \& M. Cáceres, which differs from $A$. megaspermum by the eccentric ostioles and the 8 instead of 4 ascospores per ascus; $A$. macrostomum Aptroot which is similar to A. eustomum (Mont.) Müll. Arg., but differing by the 5-7-septate ascospores $65-85 \times 16-19 \mu \mathrm{m}$.; A. megeustomum Aptroot \& Fraga Júnior which is similar to Astrothelium eustomum, but with muriform ascospores $117-125 \times 17-21 \mu \mathrm{m} ; A$. pictum Aptroot with 5-septate ascospores, red crystals in the pseudostroma medulla and lichexanthone in the thallus; $A$. rubrocrystallinum Aptroot \& M. Cáceres which is similar to $A$. annulare, but with copious red crystals in a thick layer around the ascomata and ascospores 22-27 $\times 7-9 \mu \mathrm{m} ; A$. simplex Aptroot \& S. M. A. Martins with 3-septate ascospores and a very rough thallus, differing from $A$. sinuosum by the lack of lichexanthone; $A$. sinuosum Aptroot $\&$ Gumboski with an ostiolar UV+ yellow reaction, bullate thallus and a wavy gelatinous sheath around the ascospores; $A$. tetrasporum Aptroot \& M. Cáceres which is similar to A. puiggarii, but differs by the noninspersed hamathecium and the ascus that contains only 4 ascospores; Polymeridium endoflavens Aptroot, D. S. Andrade \& M. Cáceres with yellow oil inspersion in the hamathecium and 5-7-septate ascospores 32-37 $\times 10-13 \mu \mathrm{m} ; P$. longiflavens Aptroot, Mendonça \& M. Cáceres with yellow oil inspersion in the hamathecium, an apical ostiole and 9-11-septate ascospores $57-70 \times 12-14 \mu \mathrm{m}$; Trypethelium luteolucidum Aptroot, Mendonça \& M. Cáceres which is similar to T. regnellii, but differs by the presence of anthraquinone crystals in the pseudostromata; and Viridothelium leptoseptatum Aptroot \& M. Cáceres, resembling Astrothelium aeneum but with no pigment on the thallus, a thin to absent thallus cover on the ascomata and thin-walled, constricted ascospores with lumina of a similar shape to the ascospore cell walls. Most are known only from Brazil, but a few are also known from Mexico, Puerto Rico, and/or Guyana. North-eastern Brazil is the centre of diversity of the genus Polymeridium, with 33 species now known.
\end{abstract}

Key words: Astrothelium, Guyana, lichens, Mexico, Polymeridium, Puerto Rico, taxonomy, Trypethelium, Viridothelium

Accepted for publication 29 November 2015

A. Aptroot: ABL Herbarium, G. v. d. Veenstraat 107, NL-3762 XK Soest, The Netherlands. Email: andreaptroot@gmail.com

C. O. Mendonça: Programa de Pós-Graduação, Departamento de Micologia, Universidade Federal de Pernambuco, CEP: 50670-901, Recife, Pernambuco, Brazil.

D. S. Andrade, J. R. Silva and M. E. S. Cáceres: Departamento de Biociências, Universidade Federal de Sergipe, CEP: 49500-000, Itabaiana, Sergipe, Brazil.
S. M. A. Martins: Fundação Zoobotânica do Rio Grande do Sul, Rua Dr. Salvador França 1427, CEP: 90690-000, Porto Alegre, Rio Grande do Sul, Brazil. E. Gumboski: Programa de Pós-Graduação em Botânica, Universidade Federal do Rio Grande do Sul, Av. Bento Gonçalves, 9500, Agronomia, 91501-970, Porto Alegre, Rio Grande do Sul, Brazil.

C. A. V. Fraga Júnior: Programa de Pós-Graduação em Botânica, Departamento de Botânica, Universidade Federal do Paraná, CEP 81531-980, Curitiba, Paraná, Brazil. 


\section{Introduction}

The Atlantic forest biome stretches along most of the east coast of Brazil. It is considered one of the world's biodiversity hotspots (Myers et al. 2000). As it is generally easy to access, much of its rainforest has been logged or developed (Thomas 2008). It is an originally large forested region which, in addition to lowland rainforest, also includes montane forest and is locally intermixed with some Caatinga and Restinga vegetation, often in a mosaic pattern. It is rich in unique corticolous lichens (Cáceres 2007; Cáceres et al. 2014).

Brazil seems to have by far the largest number of Trypetheliaceae. In recent years, increasing numbers of lichenologists and students have been exploring the lichen flora of Brazil. In the process, several undescribed species were found (Cáceres 2007; Cáceres et al. 2014). New Trypetheliaceae from the region have been described recently, especially in the genus Polymeridium (Aptroot et al. 2013; Aptroot \& Cáceres 2014), which has its world centre of diversity in north-eastern Brazil.

This paper describes a large number of undescribed Trypetheliaceae from the northern and southern stretches of Atlantic rainforest that we are currently aware of, plus one from the Amazonian forest. The generic concept applied here follows the phylogenetic studies by Nelsen et al. (2014). All species are keyed out in Aptroot \& Lücking (2016).

\section{Material and Methods}

Identification and descriptive work was carried out in Itabaiana, Universidade Federal de Sergipe, using a Leica EZ4 stereomicroscope and a Leica DM500 compound microscope, and also in Soest using an Olympus SZX7 stereomicroscope and an Olympus BX50 compound microscope with interference contrast, connected to a Nikon Coolpix digital camera. Sections were mounted in tap water, in which all measurements were also taken. The chemistry of all specimens was investigated under UV light, and spot tests with $10 \% \mathrm{KOH}$ were usually carried out. The chemistry of the type specimens was investigated by thinlayer chromatography (TLC) using solvent A (Orange et al. 2001).

\section{The Species}

\section{Astrothelium aeneoides Aptroot sp. nov.}

\author{
MycoBank No.: MB 815143
}

Astrothelium differing from $A$. aeneum (Eschw.) Aptroot \& Lücking by the absence of pigment on the thallus, but medulla of pseudostroma $\mathrm{K}+$ blood red and ascospores 3-septate, lumina diamond-shaped.

Type: Brazil, Minas Gerais, Serra do Caraça, Parque Natural do Caraça, alt. 1250 m, 16 September 1997, A. Aptroot 40921 (SP-holotype; ABL-isotype).

\section{(Fig. 1A)}

Thallus corticate, smooth, somewhat shiny, continuous, covering areas $\leq 8 \mathrm{~cm}$ diam., c. $0.2 \mathrm{~mm}$ thick, olive-green to olivegrey, not surrounded by a prothallus, not inducing gall formation of the host bark.

Ascomata globose, $0.7-1.0 \mathrm{~mm}$ diam., immersed in groups of $2-5$ in pseudostromata with surfaces different from that of the thallus and which are distinctly raised above the thallus, irregular to often linear in outline, sides sloping, whitish mottled with orange inside with a cream layer containing bark tissue. Wall dark brown all around, $\leq c .70 \mu \mathrm{m}$ thick. Ostioles apical, not fused, flat to concave, brown. Hamathecium not inspersed with oil globules. Asci with 8 ascospores. Ascospores hyaline, 3-septate, fusiform, 20-25 × 6-9 $\mu \mathrm{m}$, ends rounded, lumina diamond-shaped, not surrounded by a gelatinous layer.

Pycnidia not observed.

Chemistry. Thallus surface UV-, thallus medulla $\mathrm{K}-$; pseudostroma surface UV+ pink to orange, medulla of pseudostroma $\mathrm{K}+$ blood red. TLC: an anthraquinone, probably parietin.

Ecology and distribution. On smooth bark of trees in rainforest. Known from Brazil, Guyana and Puerto Rico.

Discussion. This species is closest to $A$. aenascens Aptroot, which differs by the inspersed hamathecium. Both are named after the somewhat reminiscent species A. aeneum (Eschw.) Aptroot, which mainly differs in the orange pigment on the thallus. 

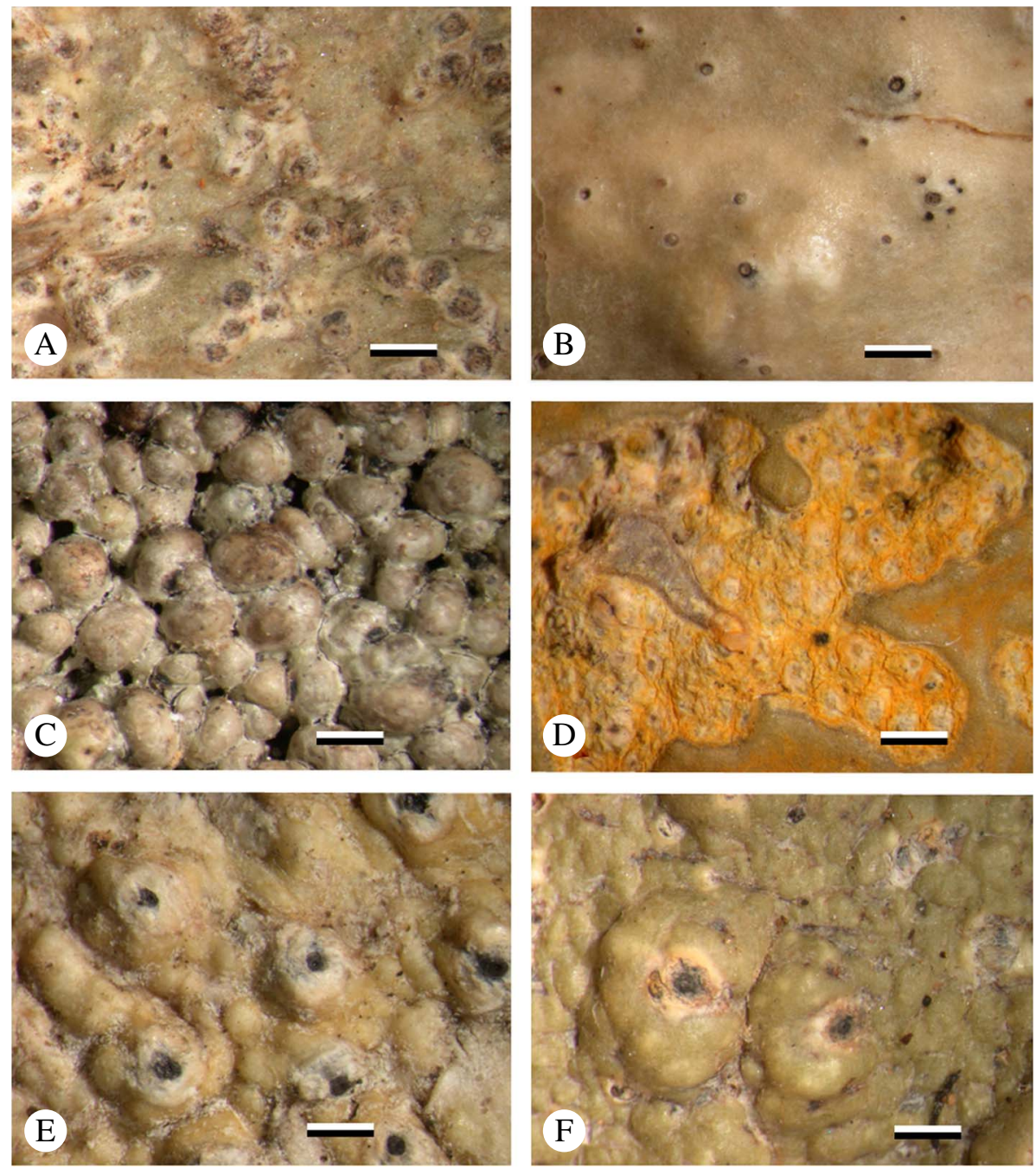

FIG. 1. Habitus of new species of Trypetheliaceae (isotypes). A, Astrothelium aeneoides; B, A. curvatum; C, A. globosum; D, A. graphicum; E, A. longisporum; F, A. macrostomum. Scale $=1 \mathrm{~mm}$. In colour online.

Additional specimens examined. Brazil: same as the type, A. Aptroot 40905, 50906 \& 50911 (ABL, SP, topotypes).-Puerto Rico: Distr. Mayagüez: Reserva Forestal Maricao, 1989, A. \& M. Aptroot 24947 (ABL).-Guyana: Potaro-Siparuni Region: Kaieteur Falls National Park, 1996, H. F. M. Sipman 40590 (B).

\section{Astrothelium curvatum Aptroot \& M. Cáceres sp. nov.}

MycoBank No.: MB 815144
Astrothelium with immersed pyriform ascomata with lateral ostioles and bent, muriform ascospores $74-90 \times$ 25-34 $\mu \mathrm{m}$.

Type: Brazil, Sergipe, Parque Nacional Serra de Itabaiana, S slope, alt. c. $400 \mathrm{~m}$, on bark of tree, 10 May 2014, M. E. S. Cáceres E A. Aptroot 21781 (ISE-holotype; ABL - isotype).

(Figs 1B \& 3F)

Thallus corticate, smooth, somewhat shiny, continuous, covering areas $\leq 3 \mathrm{~cm}$ diam., less than $0.1 \mathrm{~mm}$ thick, olive-green, 
surrounded by a black prothallus, not inducing gall formation of the host bark.

Ascomata pyriform, 0.4-0.7 $\times 0.3-0.5 \mathrm{~mm}$, single, immersed in the thallus and mostly immersed in bark. Wall carbonized all around, $\leq c . \quad 100 \mu \mathrm{m}$ thick. Ostioles lateral, not fused, flat or depressed, brown. Hamathecium inspersed with hyaline oil globules. Asci with 4-8 ascospores. Ascospores hyaline, muriform, ellipsoid, 74-90 $\times 25-$ $34 \mu \mathrm{m}$, usually bent, ends rounded, without a distinctly thickened median septum, not surrounded by a gelatinous layer.

Pycnidia not observed.

Chemistry. Thallus surface UV-, thallus medulla K-. TLC: no secondary substances detected.

Ecology and distribution. On smooth bark of trees in Atlantic rainforest. Known only from Brazil.

Discussion. This species is characterized by the immersed pyriform ascomata with lateral ostioles and the curved muriform ascospores. It is closest to Astrothelium puiggarii (Müll. Arg.) Aptroot \& Lücking, which differs by having 2 ascospores in the ascus instead of 4-8.

\section{Astrothelium globosum Aptroot \&} M. Cáceres sp. nov.

\section{MycoBank No.: MB 815145}

Astrothelium with immersed ascomata, a thallus consisting of nearly globose warts and 3-septate ascospores, $35-40 \times 11-13 \mu \mathrm{m}$.

Type: Brazil, Sergipe, Santa Luzia do Itanhy, Mata do Crasto, on bark of tree, 10 March 2012, M. E. S. Cáceres 12980 (ISE-holotype).

(Fig. 1C)

Thallus corticate, consisting of closely appressed, nearly globose warts $0.3-0.9 \mathrm{~mm}$ diam., with a thick hyaline cortex, covering areas $\leq 3 \mathrm{~cm}$ diam., $\leq c .0 .9 \mathrm{~mm}$ thick, pale greyish green, not surrounded by a prothallus, not inducing gall formation of the host bark.

Ascomata pyriform, $0 \cdot 2-0.4 \mathrm{~mm}$ diam., $2-5$ aggregated, immersed in the bark, only visible from above by black ostioles between the thallus warts. Wall carbonized, $\leq c .50 \mu \mathrm{m}$ thick. Ostioles eccentric, brown. Hamathecium not inspersed. Ascospores 8 per ascus, hyaline, 3-septate, long ellipsoid, 35-40 × 11-13 $\mu \mathrm{m}$, lumina diamond-shaped, surrounded by a sheath of gelatinous material c. $3 \mu \mathrm{m}$ thick at the sides and $c .7 \mu \mathrm{m}$ wide at the tips of the ascospores.

Pycnidia not observed.

Chemistry. Thallus surface UV-, thallus medulla K-. TLC: no secondary substances detected.

Ecology and distribution. On smooth bark of trees in lowland Atlantic rainforest. Known only from Brazil.

Discussion. This species has a very characteristic thallus consisting of almost globose warts, very three-dimensional for a crustose lichen. It is closest to $A$. simplex (see below), which has longer ascospores.

\section{Astrothelium graphicum Aptroot \& S. M. A. Martins sp. nov.}

\section{MycoBank No.: MB 815146}

Astrothelium with an extended, reticulate pseudostroma, which is lower than the slightly bullate thallus, orange pruina on the thallus and pseudostroma, and muriform ascospores, 60-66 × 12-16 $\mu \mathrm{m}$.

Type: Brazil, Pará, Santarem, September 2013, A. L. Burligo Miranda (HAS-holotype; ABL-isotype).

\section{(Fig. 1D)}

Thallus corticate, smooth to somewhat bullate, somewhat shiny, continuous, covering areas $\leq 4 \mathrm{~cm}$ diam., c. $0.3 \mathrm{~mm}$ thick, green with thin orange pruina, not surrounded by prothallus, not inducing gall formation of the host bark.

Ascomata globose, $0.3-0.4 \mathrm{~mm}$ diam., mostly aggregated $10-40$, immersed in or even below pseudostromata with a surface different from the thallus; pseudostromata not distinctly lower than the thallus, irregular in outline, anastomosing to meandering in a reticulate pattern, $\leq c .5 \mathrm{~mm}$ diam. (but total network covering c. $50 \%$ of the whole 
thallus), ochraceous with thin orange pruina, inside ochraceous, not containing bark tissue, but ascomata often immersed in the bark. Wall carbonized, $\leq c .80 \mu \mathrm{m}$ thick. Ostioles apical, not fused, flat, ochraceous to brown, surrounded by a whitish to ochraceous, often clearly exserted ring of c. $0.1 \mathrm{~mm}$. Hamathecium not inspersed with oil globules. Asci with 8 ascospores. Ascospores hyaline, muriform, ellipsoid, 60$66 \times 12-16 \mu \mathrm{m}$, without a distinctly thickened median septum, ends rounded, not surrounded by a gelatinous layer.

Pycnidia not observed.

Chemistry. Thallus surface UV+ pink, thallus medulla $\mathrm{K}-$; pseudostroma surface UV+ pink, pigmented parts of pseudostroma $\mathrm{K}+$ purple. TLC: an anthraquinone, probably parietin.

Ecology and distribution. On smooth bark of trees in rainforest. Known only from Brazil.

Discussion. This species is characterized by the extended, reticulate pseudostroma, which is lower than the slightly bullate thallus, and the orange pruina on the thallus and pseudostroma, giving it the appearance of a giraffe. It is similar in aspect to $A$. flavomaculatum Aptroot, which mainly differs by much larger ascospores $140-200 \times 25-30 \mu \mathrm{m}$.

\section{Astrothelium longisporum Aptroot, J. R. Silva \& M. Cáceres sp. nov.}

\author{
MycoBank No.: MB 815147
}

Astrothelium differing from A. megaspermum (Mont.) Aptroot \& Lücking by the eccentric ostioles and the 8 instead of 4 ascospores per ascus.

Type: Brazil, Sergipe, Poço Redondo, Serra da Guia, on bark of tree, 26 January 2014, F. A. R. Silva T2A29 (ISE-holotype).

\section{(Fig. 1E)}

Thallus corticate, somewhat bullate, somewhat shiny, continuous, covering areas $\leq 6 \mathrm{~cm}$ diam., c. $0.2 \mathrm{~mm}$ thick, pale olivegreen, surrounded by a black prothallus c. $0.3 \mathrm{~mm}$ wide, not inducing gall formation of the host bark.
Ascomata globose, $0.8-1.2 \mathrm{~mm}$ diam., single, in hemispherical warts covered by thallus, sides sloping. Wall carbonized, $\leq c .50 \mu \mathrm{m}$ thick. Ostioles eccentric, flat, black, surrounded by an irregular whitish decorticate spot of c. $0.5 \mathrm{~mm}$. Hamathecium not inspersed with oil globules. Asci with 8 ascospores. Ascospores hyaline, muriform, fusiform, 200-230 ×30-40 $\mu \mathrm{m}$, without a distinctly thickened median septum, ends rounded, not surrounded by a gelatinous layer.

Pycnidia not observed.

Chemistry. Thallus surface UV-, thallus medulla $\mathrm{K}-$; also decorticated ascoma surface UV-. TLC: no secondary substances detected.

Ecology and distribution. On smooth bark of trees in Atlantic rainforest. Known only from Brazil.

Discussion. This species looks much like Astrothelium megaspermum, which differs by the central ostioles and the 4 instead of 8 ascospores per ascus.

\section{Astrothelium macrostomum Aptroot sp. nov.}

MycoBank No.: MB 815148

Astrothelium similar to $A$. eustomum (Mont.) Müll. Arg., but differing by the 5-7-septate ascospores of $65-85 \times 16-19 \mu \mathrm{m}$

Type: Brazil, Minas Gerais, Serra do Caraça, Parque Natural do Caraça, 16 September 1997, H. F. M. Sipman 41025 (SP-holotype; B-isotype).

(Fig. 1F)

Thallus corticate, smooth, somewhat shiny, continuous, covering areas $\leq 7 \mathrm{~cm}$ diam., under $0.1 \mathrm{~mm}$ thick, olive-green to olive-grey, usually not surrounded by a prothallus, inducing gall formation of the host bark: lower bark or cambium layer locally swollen and erupting through the upper bark.

Ascomata pyriform, c. $0 \cdot 6-1.2 \mathrm{~mm}$ diam., mostly aggregated $2-5$, mostly immersed in the bark tissue. Wall carbonized, $\leq c .80 \mu \mathrm{m}$ thick. Ostioles eccentric, fused, flat, white-pruinose, surrounded by a whitish zone. Hamathecium not inspersed with oil 
globules. Asci with 8 ascospores. Ascospores hyaline, 5-7-septate, fusiform, 65-85 $\times$ $16-19 \mu \mathrm{m}$, ends pointed, lumina diamondshaped, not surrounded by a gelatinous layer.

Pycnidia not observed.

Chemistry. Thallus surface UV-, thallus medulla $\mathrm{K}-$; ostiolar region $\mathrm{UV}+$ yellow. TLC: lichexanthone.

Ecology and distribution. On smooth bark of trees in rainforest. Known from Brazil, Guyana and Venezuela.

Discussion. This species is similar to Astrothelium eustomum, but differs by the 5-7septate rather than 3-5-septate, and much larger, ascospores. Astrothelium diplocarpoides Müll. Arg. is similar in these characters, but has an inspersed hamathecium and the whole thallus contains lichexanthone.

Additional specimens examined. Guyana: Upper Mazaruni Distr.: Paruima Mission, 1997, H. F. M. Sipman 39711 (B).-Venezuela: Bolivar: Cerro Guaiquinima, alt. 1000 m, 1990, H. F. M. Sipman 26701 (B).

\section{Astrothelium megeustomum Aptroot \& Fraga Jr sp. nov.}

MycoBank No.: MB 815149

Astrothelium similar to Astrothelium eustomum (Mont.) Müll. Arg., but with muriform ascospores 117-125× $17-21 \mu \mathrm{m}$.

Type: Brazil, Paraná, Guaratuba, Brejatuba, alt. c. $10 \mathrm{~m}$, on tree bark in arboreal restinga, 8 May 2015, C. A. V. Fraga funior 840 (UPCB-holotype; ABLisotype).

(Fig. 2A)

Thallus corticate, smooth, somewhat shiny, continuous, covering areas $\leq 7 \mathrm{~cm}$ diam., c. $0.2 \mathrm{~mm}$ thick, pale yellowish green, not surrounded by prothallus, not inducing gall formation of the host bark.

Ascomata pyriform, c. $0.6-1.2 \mathrm{~mm}$ diam., mostly aggregated $2-5$, mostly immersed in the bark tissue below pseudostromata with a surface not much different from the thallus, and which are distinctly raised above the thallus and mostly irregular in outline, not forming a network. Wall carbonized, $\leq c .80 \mu \mathrm{m}$ thick. Ostioles eccentric, fused, flat, pale brownish, white-pruinose, surrounded by a whitish zone. Hamathecium not inspersed with oil globules. Asci with 8 ascospores. Ascospores hyaline, muriform, fusiform, 117-125 × 17-21 $\mathrm{m}$, ends pointed, surrounded by a gelatinous layer $\leq 10 \mu \mathrm{m}$ thick, median septum thickened.

Pycnidia not observed.

Chemistry. Thallus surface UV-, thallus medulla $\mathrm{K}-$; ostiolar region $\mathrm{UV}+$ yellow. TLC: lichexanthone.

Ecology and distribution. On smooth bark of trees in primary forest. Known only from Brazil.

Discussion. This species is similar to Astrothelium eustomum, but differs by the muriform rather than 3-5-septate ascospores. The also newly described $A$. eustomuralis Aptroot \& M. Cáceres has submuriform ascospores.

\section{Astrothelium pictum Aptroot sp. nov.}

\section{MycoBank No.: MB 815150}

Astrothelium with 5-septate ascospores, red crystals in the pseudostroma medulla and lichexanthone in the thallus.

Type: Brazil, Minas Gerais, Serra do Caraça, Parque Natural do Caraça, alt. $1300 \mathrm{~m}$, September 1997, A. Aptroot 40608 (SP-holotype; ABL-isotype).

(Fig. 2B)

Thallus bullate, smooth, somewhat shiny, continuous, covering areas $\leq 5 \mathrm{~cm}$ diam., c. $0.2 \mathrm{~mm}$ thick, olive-green to olive-grey, not surrounded by a prothallus, inducing gall formation of the host bark.

Ascomata globose, $0.8-1.2 \mathrm{~mm}$ diam., immersed in groups or lines of 5-25 in pseudostromata with a surface different from the thallus, which are not distinctly raised above the thallus and irregular to linear in outline, whitish, inside with red crystals. Wall black all around, $\leq c .70 \mu \mathrm{m}$ thick. Ostioles apical, not fused, flat, brown. Hamathecium not inspersed with oil globules. Asci with 8 ascospores. Ascospores hyaline, (3-)5-septate, fusiform, 90-115 $\times 22$ $27 \mu \mathrm{m}$, ends rounded, lumina diamond-shaped, not surrounded by a gelatinous layer. 

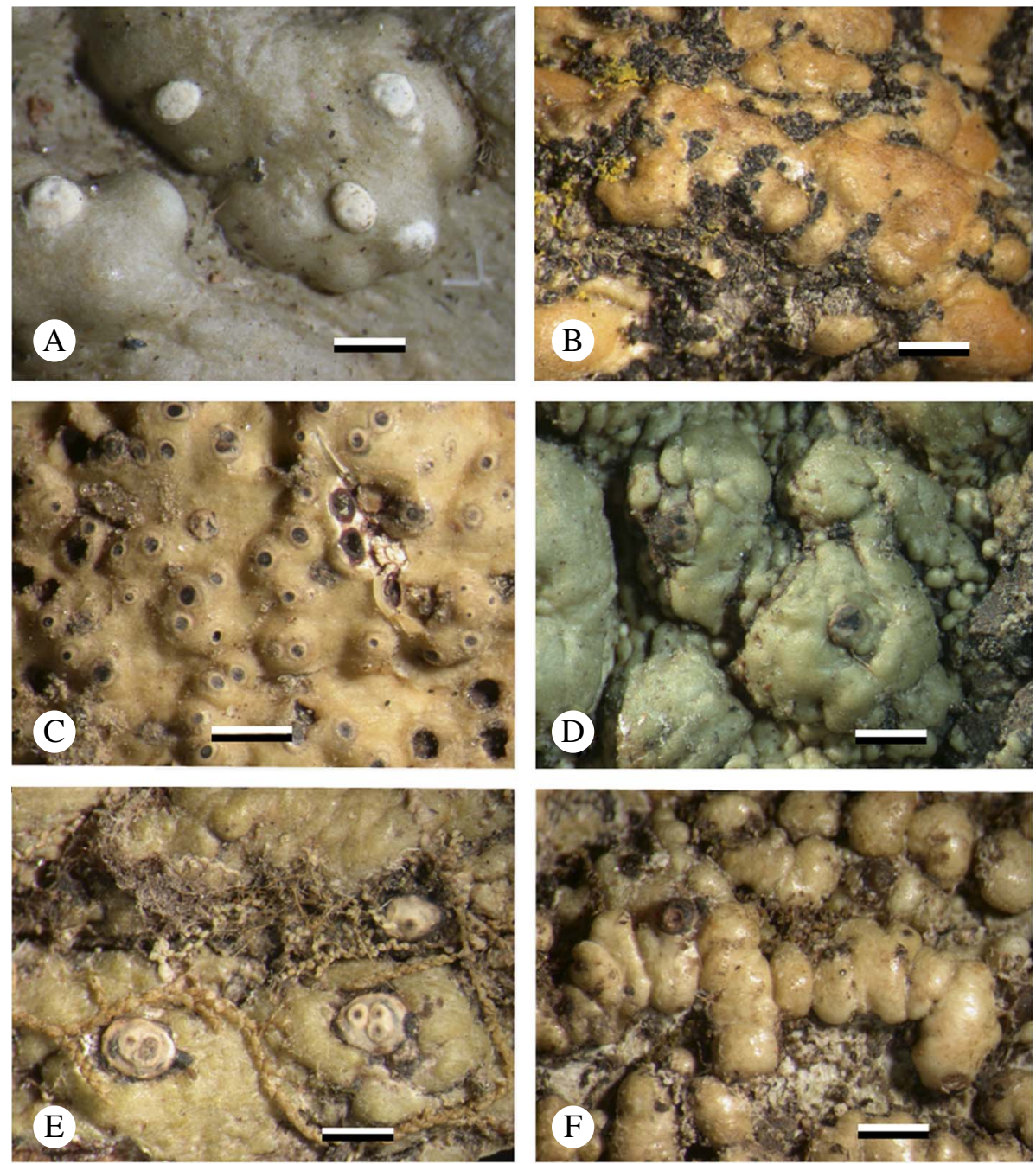

FIg. 2. Habitus of new species of Trypetheliaceae (isotypes). A, Astrothelium megeustomum; B, A. pictum; C, A. rubrocrystallinum; D, A. simplex; E, A. sinuosum; F, A. tetrasporum. Scales: A, B \& D-F = $1 \mathrm{~mm}$; $\mathrm{C}=0.2 \mathrm{~mm}$. In colour online.

Pycnidia not observed.

Chemistry. Thallus surface UV+ yellow, crystals in pseudostroma medulla $\mathrm{K}+$ purple. TLC: an anthraquinone and lichexanthone.

Ecology and distribution. On smooth bark of trees in Atlantic rainforest. Known only from Brazil.

Discussion. This is one of the few trypethelioid Astrothelium species with 5-septate ascospores. It differs from all other species with 5-septate ascospores by the presence of red crystals in the pseudostroma medulla and lichexanthone in the thallus. Astrothelium sipmanii (see below) comes closest, but it differs by an inspersed hamathecium.

\section{Astrothelium rubrocrystallinum Aptroot \& M. Cáceres sp. nov.}

MycoBank No.: MB 815151 
Astrothelium similar to A. annulare (Mont.) Aptroot \& Lücking, but with copious red crystals in a thick layer around the ascomata, and ascospores $22-27 \times 7-9 \mu \mathrm{m}$.

Type: Brazil, Sergipe, Santa Luzia do Itanhy, Mata do Junco, alt c. $150 \mathrm{~m}$, on bark of tree, 15 April 2011, M. E. S. Cáceres 7409 (ISE-holotype).

(Fig. 2C)

Thallus bullate, smooth, somewhat shiny, continuous, covering areas $\leq 5 \mathrm{~cm}$ diam., c. $0.2 \mathrm{~mm}$ thick, olive-brown, surrounded by a black prothallus line $c .0 \cdot 2 \mathrm{~mm}$ wide, not inducing gall formation of the host bark.

Ascomata globose, $0.30-0.45 \mathrm{~mm}$ diam., mostly in groups or lines of $2-5$ in poorly distinguished pseudostromata, which are mostly distinctly raised above the thallus, of thallus colour, inside with a dense layer of red crystals $c .0 .2 \mathrm{~mm}$ wide all around the ascoma wall, which is visible from above as dark granules through the hyaline cortex around the ostiole. Wall black all around, $\leq c .50 \mu \mathrm{m}$ thick. Ostioles apical, not fused, flat, black, surrounded by an ochraceous ring of c. $0.2 \mathrm{~mm}$, which itself sometimes has a grey margin. Hamathecium inspersed with hyaline oil globules. Asci with 8 ascospores. Ascospores hyaline, 3-septate, fusiform, 22-27 $\times 7-9 \mu \mathrm{m}$, ends rounded, lumina diamond-shaped, not surrounded by a gelatinous layer.

Pycnidia not observed.

Chemistry. Thallus surface UV-, crystals in pseudostroma medulla $\mathrm{K}+$ purple. TLC: an anthraquinone.

Ecology and distribution. On smooth bark of trees in Atlantic rainforest. Known only from Brazil.

Discussion. This species belongs to the Astrothelium annulare group, and is characterized by the copious red crystals in a thick layer around the ascomata. Astrothelium buckii (R. C. Harris) Aptroot \& Lücking comes closest, but has longer ascospores of (32-)37-47 × 14-16 $\mu \mathrm{m}$.

\section{Astrothelium simplex Aptroot \& S. M. A. Martins sp. nov.}

MycoBank No.: MB 815152
Astrothelium with 3-septate ascospores and a very rough thallus, differing from $A$. sinuosum Aptroot \& Gumboski by the lack of lichexanthone.

Type: Brazil, Rio Grande do Sul, Caraá, Fraga, 27 April 2009, S. M. A. Martins 2274 (HAS49654holotype; ABL-isotype).

(Fig. 2D)

Thallus corticate, bullate, somewhat shiny, continuous, covering areas $\leq 7 \mathrm{~cm}$ diam., c. $0.3 \mathrm{~mm}$ thick, olive-green, not surrounded by a prothallus, inducing gall formation of the host bark.

Ascomata pyriform, c. $0.6-0.9 \mathrm{~mm}$ diam., mostly aggregated $2-5$, mostly immersed in the bark tissue. Wall carbonized, $\leq c .80 \mu \mathrm{m}$ thick. Ostioles eccentric, fused, raised, dark brown, surrounded by an ochraceous zone. Hamathecium not inspersed with oil globules. Asci with 8 ascospores. Ascospores hyaline, 3-septate, fusiform, $56-63 \times 15-19 \mu \mathrm{m}$, ends pointed, lumina diamond-shaped, without gelatinous sheath.

Pycnidia not observed.

Chemistry. Thallus surface UV-, thallus medulla K-; TLC: no substances detected.

Ecology and distribution. On smooth bark of trees in Atlantic rainforest. Known only from Brazil.

Discussion. This species differs from the next species by the lack of lichexanthone and lack of a gelatinous sheath, and the general simplicity in morphological structures (hence the name). Astrothelium globosum (see above) is also similar, but has shorter ascospores.

\section{Astrothelium sinuosum Aptroot \& Gumboski sp. nov.}

\section{MycoBank No.: MB 815153}

Astrothelium with an ostiolar UV+ yellow reaction, bullate thallus and a wavy gelatinous sheath around the ascospores.

Type: Brazil, Santa Catarina, São Bento do Sul, Área de Proteção Ambiental Rio Vermelho, Humboldt, 6 September 2012, E. Gumboski 3906 (HAS-holotype; ABL-isotype).

(Figs 2E, 3D \& E) 
Thallus corticate, bullate, somewhat shiny, continuous, covering areas $\leq 7 \mathrm{~cm}$ diam., c. $0.2 \mathrm{~mm}$ thick, olive-green, not surrounded by a prothallus, inducing gall formation of the host bark.

Ascomata pyriform, c. $0.6-1.2 \mathrm{~mm}$ diam., mostly aggregated 2-5, mostly immersed in the bark tissue. Wall carbonized, $\leq c$. $80 \mu \mathrm{m}$ thick. Ostioles eccentric, fused or with 2-3 together next to each other in the same ostiolar region, raised, brown, surrounded by a raised, c. $0 \cdot 2-0.4 \mathrm{~mm}$ wide, whitish zone. Hamathecium not inspersed with oil globules. Asci with 8 ascospores. Ascospores hyaline, 3-septate, fusiform, $62-67 \times 17-20 \mu \mathrm{m}$, ends pointed, lumina diamond-shaped, surrounded by a rather irregular and often discontinuous, wavy gelatinous sheath $\leq 4 \mu \mathrm{m}$ thick, which is at least present at the central septum and at the poles.

Pycnidia not observed.

Chemistry. Thallus surface UV-, thallus medulla $\mathrm{K}-$; ostiolar region $\mathrm{UV}+$ yellow. TLC: lichexanthone.

Ecology and distribution. On smooth bark of trees in Atlantic rainforest. Known only from Brazil.

Discussion. This species is similar to the preceding species, but differs in the ostiolar UV reaction and the wavy gelatinous sheath around the ascospores. Astrothelium globosum (see above) is also similar, but has shorter ascospores.

\section{Astrothelium tetrasporum Aptroot \& M. Cáceres sp. nov.}

\section{MycoBank No.: MB 815154}

Astrothelium similar to A. puiggarii (Müll. Arg.) Aptroot \& Lücking, but differing by the non-inspersed hamathecium and the ascus that contains only 4 ascospores.

Type: Brazil, São Paulo, Botucatu, near Pousada Mandala on SP-254, c. $850 \mathrm{~m}, 9$ September 2012, M. E. S. Cáceres $\mathcal{E} A$. Aptroot 13562 (SP - holotype; ABL - isotype).

(Fig. 2F)

Thallus corticate, discontinuous, consisting of sinuose to moniliform rows of globose to slightly flattened bullate areas that become locally almost like thick squamules, which mostly consist of a hyaline cortex of $\leq 230 \mu \mathrm{m}$, somewhat shiny, covering areas $\leq 10 \mathrm{~cm}$ diam., olive-green.

Ascomata pyriform, 0.7-1.3 mm diam., single, immersed in the thallus. Wall carbonized, $\leq c .70 \mu \mathrm{m}$ thick. Ostioles apical to eccentric, not fused, erumpent, brown, chimney-like. Hamathecium not inspersed with oil globules. Asci with 4 ascospores. Ascospores hyaline, muriform, fusiform, 145-175 $\times$ $30-35 \mu \mathrm{m}$, ends rounded, when young with a markedly thickened median septum, with two c. $5 \mu \mathrm{m}$ thick polar gelatinous caps.

Pycnidia not observed.

Chemistry. Thallus surface UV-, thallus medulla K-. TLC: no secondary substances detected.

Ecology and distribution. On smooth bark of trees in dry forest, including a forest remnant in a botanical garden. Known only from Brazil.

Discussion. This species has the appearance of $A$. puiggarii, but that species differs by the inspersed hamathecium and the ascus that contains only 2 ascospores. Astrothelium curvatum (see above) is also similar; it has an inspersed hamathecium and 4-8 ascospores in the ascus.

Additional material examined. Brazil: São Paulo: Botucatu, botanical garden on campus, 2012, M. Cáceres $\mathcal{E}$ A. Aptroot 13562 (SP, ABL); Serra da Mantiqueira, Campos de Jordão, 1997, A. Aptroot 41697 (ABL). Minas Gerais: Serra da Mantiqueira, Fazenda São Mateus, 1980, Kalb (hb. Kalb).

\section{Polymeridium endoflavens Aptroot, D. S. Andrade \& M. Cáceres sp. nov.}

\section{MycoBank No.: MB 815155}

Polymeridium with yellow oil inspersion in the hamathecium and 5-7-septate ascospores 32-37 ×10-13 $\mu \mathrm{m}$.

Type: Brazil, Sergipe, Santa Luzia do Itanhy, Mata do Junco, alt c. $150 \mathrm{~m}$, on bark of tree, 10 February 2014 , D. S. Andrade T1A3 (ISE-holotype).

(Fig. 3A)

Thallus not corticate, dull, continuous, covering areas $\leq 2 \mathrm{~cm}$ diam., whitish, 

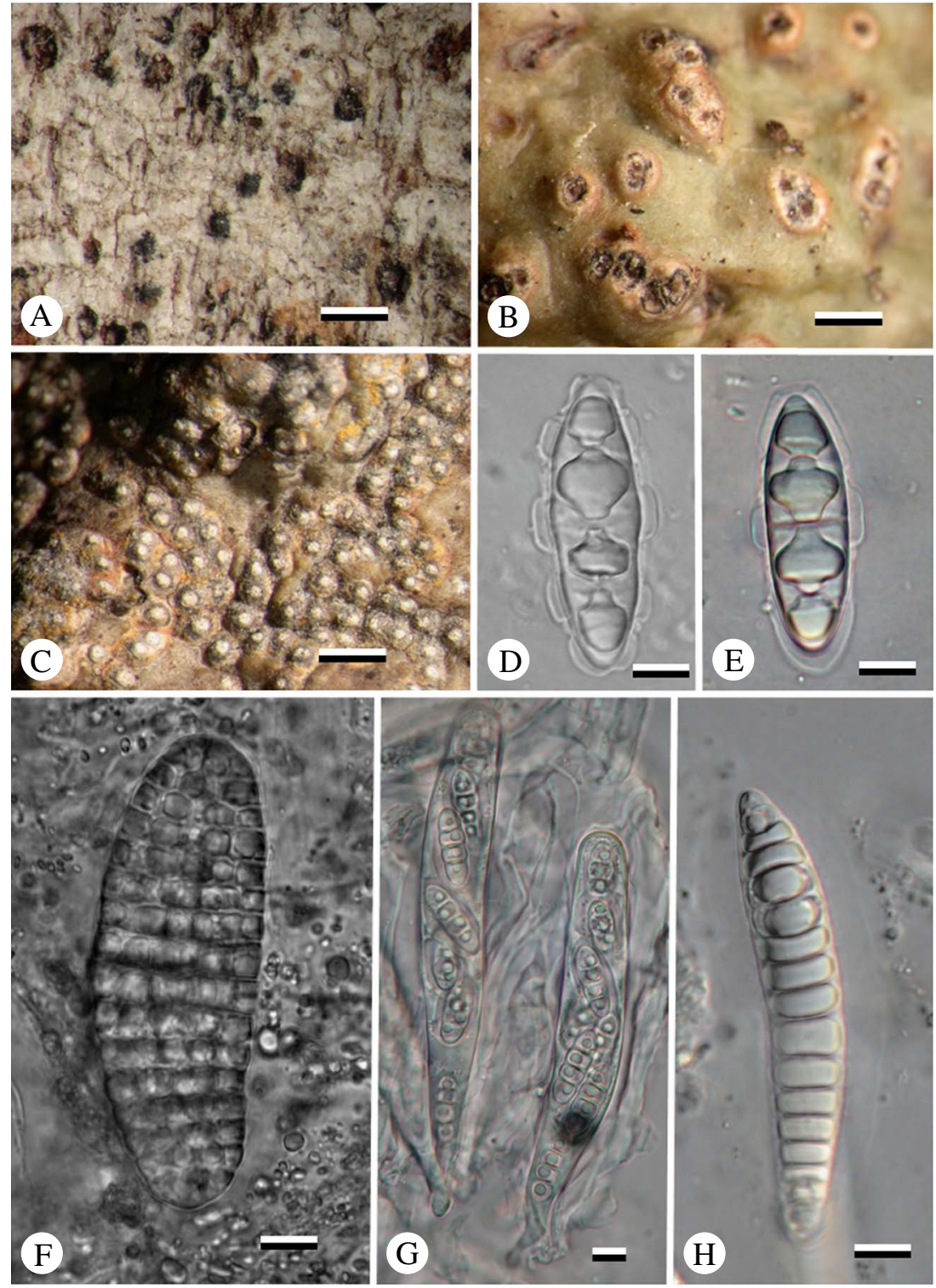

FIG. 3. Habitus of new species of Trypetheliaceae (isotypes). A-C, habitus. A, Polymeridium endoflavens; B, Trypethelium luteolucidum; C, Viridothelium leptoseptatum. D-H, ascospores. D \& E, Astrothelium sinuosum showing the gelatinous sheath with wavy outline; F, Astrothelium curvatum; G, Viridothelium leptoseptatum, asci; $\mathrm{H}$, Trypethelium luteolucidum. Scales: A-C $=1 \mathrm{~mm} ; \mathrm{D}-\mathrm{H}=10 \mu \mathrm{m}$. In colour online.

surrounded by a black prothallus line c. $0.6 \mathrm{~mm}$ wide, not inducing gall formation of the host bark.

Ascomata globose, $0.25-0.35 \mathrm{~mm}$ diam., single, emergent from the thallus. Wall carbonized, $\leq c .40 \mu \mathrm{m}$ thick. Ostioles apical, not fused, flat, black. Hamathecium inspersed with yellow oil globules. Asci with 8 ascospores. Ascospores hyaline, 5-7septate, fusiform, $32-37 \times 10-13 \mu \mathrm{m}$, ends 


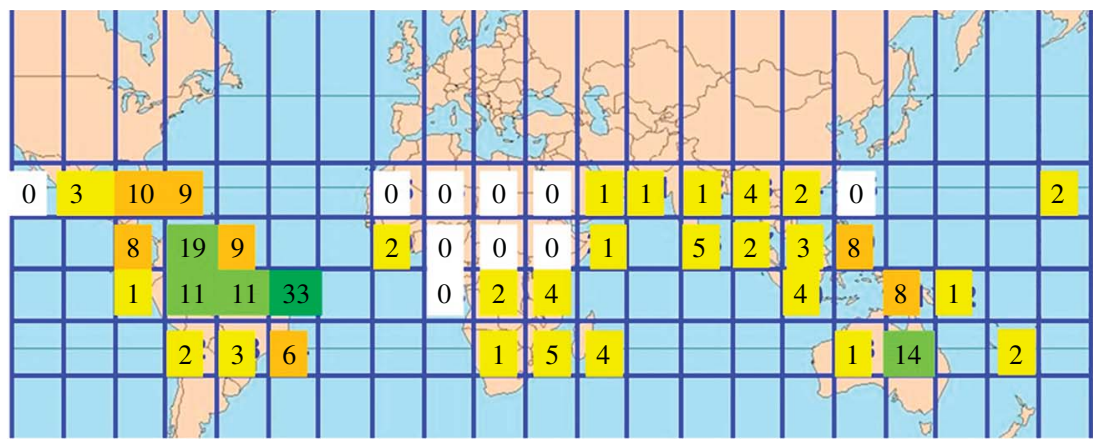

FIG. 4. World distribution of Polymeridium; number of accepted species per $15^{\circ} \times 15^{\circ}$ area. In colour online.

pointed, lumina rounded, not surrounded by a gelatinous layer.

Pycnidia not observed.

Chemistry. Thallus surface UV+ yellow, thallus medulla $\mathrm{K}-$. TLC: lichexanthone.

Ecology and distribution. On smooth bark of trees in Atlantic rainforest. Known only from Brazil.

Discussion. Yellow oil inspersion in the hamathecium is a rare character, and in the family is otherwise known only from a few Astrothelium and Pseudopyrenula species, and in the genus Polymeridium from P. flavothecium R. C. Harris and the species below. These species differ by having longer and more septate ascospores. With the description of this and the next species, the number of Polymeridium species described from northeastern Brazil is now 33 (Fig. 4), much higher than anywhere else in the world. Species of the genus are also very abundant there, especially on exposed trees in Caatinga forest, where several species often grow side by side. There are not many lichen genera known with such a distinct centre of speciation.

\section{Polymeridium longiflavens Aptroot, Mendonça \& M. Cáceres sp. nov.}

\section{MycoBank No.: MB 815156}

Polymeridium with yellow oil inspersion in the hamathecium, an apical ostiole and 9-11-septate ascospores $57-70 \times 12-14 \mu \mathrm{m}$.
Type: Brazil, Sergipe, Parque Nacional Serra de Itabaiana, alt c. $400 \mathrm{~m}$, on bark of tree, 27 July 2013, M. E. S. Cáceres \& A. Aptroot 18031 (ISE-holotype; $\mathrm{ABL}$ - isotype).

Thallus not corticate, dull, continuous, covering areas $\leq 2 \mathrm{~cm}$ diam., whitish grey, surrounded by a byssoid dark brown hypothallus line $c .0 .4 \mathrm{~mm}$ wide, not inducing gall formation of the host bark.

Ascomata globose, $0.25-0.35 \mathrm{~mm}$ diam., single, emergent from the thallus. Wall carbonized, $\leq c .40 \mu \mathrm{m}$ thick. Ostioles apical, not fused, flat, black. Hamathecium inspersed with yellow oil globules. Asci with 8 ascospores. Ascospores hyaline, 9-11-septate, fusiform, $57-70 \times 12-14 \mu \mathrm{m}$, ends pointed, lumina rounded, not surrounded by a gelatinous layer.

Pycnidia not observed.

Chemistry: Thallus UV+ yellow, $\mathrm{KOH}-$. TLC: lichexanthone.

Ecology and distribution. On smooth bark of trees in transitional forest. Known only from Brazil.

Discussion. Yellow oil inspersion in the hamathecium is a rare character, and in the family is otherwise known only from a few Astrothelium and Pseudopyrenula species, and in the genus Polymeridium from $P$. flavothecium R. C. Harris (which has a lateral ostiole) and $P$. longiflavens (which has shorter and less septate ascospores).

Additional specimen examined. Brazil: Bahia: Chapada da Diamantina, Catolé, alt. c. $1200 \mathrm{~m}, 10 \mathrm{i}$ 2015, C. Mendonça (ISE 23924, ABL). 


\section{Trypethelium luteolucidum Aptroot, Mendonça \& M. Cáceres sp. nov.}

\section{MycoBank No.: MB 815157}

Trypethelium similar to $T$. regnellii Malme (syn.: $T$. globolucidum Aptroot et al.), but differing by the presence of anthraquinone crystals in the pseudostromata.

Type: Brazil, Rondônia, Porto Velho, Parque Circuito, alt. c. $100 \mathrm{~m}$, on bark of Hevea brasiliensis in plantation, 11 March 2012, M. E. S. Cáceres $\mathcal{F}$ A. Aptroot 11446 (ISE-holotype; ABL-isotype).

(Fig. 3B \& H)

Thallus corticate, smooth to somewhat bullate, somewhat shiny, continuous, covering areas $\leq 10 \mathrm{~cm}$ diam., c. $0.2 \mathrm{~mm}$ thick, ochraceous, not surrounded by a prothallus, not inducing gall formation of the host bark.

Ascomata globose, $0.4-0.7 \mathrm{~mm}$ diam., mostly aggregated $2-7$, emergent from the thallus in pseudostromata with a decorticated upper surface different from the thallus; pseudostromata distinctly raised above the thallus, irregular in outline, sides almost vertical, $\leq c$. $5 \mathrm{~mm}$ diam. and $1 \mathrm{~mm}$ high, sides concolorous with thallus; upper surface whitish pruinose or grey to blackish due to the emergent ascomata, inside with crystals. Wall carbonized, $\leq c .60 \mu \mathrm{m}$ thick. Ostioles apical, not fused, flat, brown. Hamathecium inspersed with hyaline oil globules. Asci with 8 ascospores. Ascospores hyaline, 11-21-septate, long fusiform, $60-110 \times 12-15 \mu \mathrm{m}$, ends rounded, lumina diamond-shaped, surrounded by a gelatinous layer $\leq 2 \mu \mathrm{m}$ thick.

Pycnidia not observed.

Chemistry. Thallus surface mostly UV+ yellow, K-, pseudostroma UV+ yellow, crystals $\mathrm{K}+$ yellow to red. TLC: lichexanthone and an anthraquinone.

Ecology and distribution. On smooth bark of trees in rainforest. Known from Brazil and Mexico.

Discussion. There are only a few species remaining in the genus Trypethelium s. str. (Nelsen et al. 2014), which is characterized by a corticate thallus and ascospores with rounded lumina. This new species is closest to $T$. regnellii (syn.: $T$. globolucidum), but differs by the presence of anthraquinone crystals in the pseudostromata.

Additional specimens examined. Mexico: Chiapas: Ocozocoautla, 1994, f. Wolf $\mathcal{G} H$. Sipman 224 (B).-Brazil: Rondônia: Porto Velho, Parque Circuito, alt. c. $100 \mathrm{~m}$, on bark of Hevea brasiliensis in plantation, M. Cáceres \& A. Aptroot 11391, 11441 (ISE, ABL); Paraná, Guaíra, Rio Paraná, 1980, Kalb (hb. Kalb). Sergipe: Porto da Folha, Fazenda São Pedro, C. O. Mendonça AVAT1A2 (ISE 19965).

\section{Viridothelium leptoseptatum Aptroot \& M. Cáceres sp. nov.}

\section{MycoBank No.: MB 818907}

Viridothelium resembling Astrothelium aeneum but no pigment on the thallus, with thin to absent thallus cover on the ascomata and thin-walled, constricted ascospores with lumina of a similar shape to the ascospore cell walls.

Type: Brazil, Sergipe, Parque Nacional Serra de Itabaiana, S slope, alt c. $400 \mathrm{~m}$, on bark of tree, 18 September 2013, M. Cáceres $\mathcal{E}$ A. Aptroot 18588 (ISEholotype; ABL-isotype).

\section{(Fig. 3C \& G)}

Thallus corticate, smooth, somewhat shiny, continuous, covering areas $\leq 5 \mathrm{~cm}$ diam., c. $0.2 \mathrm{~mm}$ thick, pale olive-green, surrounded by a black prothallus $c .1 \mathrm{~mm}$ wide, not inducing gall formation of the host bark.

Ascomata globose, $0.3-0.5 \mathrm{~mm}$ diam., mostly aggregated 3-20, emergent from the thallus, not forming distinct pseudostromata, surface not different from the thallus, covered by thallus or not and fully or partly free with the carbonization visible from above, always at least partly covered by yellow pigment. Wall black, $\leq c .50 \mu \mathrm{m}$ thick. Ostioles apical, not fused, flat, white. Hamathecium not inspersed with oil globules. Asci with 8 ascospores. Ascospores hyaline, 3-septate, fusiform, 23-25 $\times 7-8 \mu \mathrm{m}$, ends rounded, lumina of similar shape to the ascospore cell walls, septa thin, constricted at the septa, not surrounded by a gelatinous layer.

Pycnidia not observed.

Chemistry. Thallus surface UV-, thallus medulla $\mathrm{K}-$; pseudostroma surface $\mathrm{UV}+$ pink to orange, pigmented parts of pseudostroma 
$\mathrm{K}+$ blood red. TLC: an anthraquinone, probably parietin.

Ecology and distribution. On smooth bark of trees in Atlantic rainforest. Known only from Brazil.

Discussion. This species is somewhat reminiscent of Astrothelium aeneum, from which it differs by the absence of orange pigment on the thallus, the thin to absent thallus cover on the ascomata and the thin-walled, constricted ascospores. These ascospores might, however, be some kind of aberration where ascospores skip a step in their ontogeny and take the shape of post-mature ascospores earlier in their development. The ascospores resemble somewhat those in the genus Polymeridium, but all other details point to affinities with Viridothelium.

\section{Discussion}

Brazil seems to be by far the richest country in the world for Trypetheliaceae species. This was suggested by previous work (e.g. Harris 1986), but it has become clearer with the addition of 15 species described here and 24 by Aptroot $\&$ Cáceres (2016), as well as further species described elsewhere in this issue.

The genus Polymeridium, in which 50 species are now known (Aptroot et al. 2013; Aptroot \& Cáceres 2014), has its world centre of diversity in north-eastern Brazil, with 33 species present (Fig. 4). The explanation is at least partly that species of the genus prefer smooth-barked trees in tropical seasonal forest in the Caatinga biome in north-eastern Brazil (Thomas 2008), which provides the most suitable habitat for them. Tropical seasonal forests are also widely distributed in Africa, but here the trees are more often rough-barked. The tropical seasonal forests of South-East Asia, the so-called monsoon forests (Collinson 1977), are far higher and during much of the year too dark for these photophilic lichens. Finally, there are tropical seasonal forests in Queensland, which are partly suitable, where Polymeridium species are well represented, but this is at a different scale as the suitable area is much smaller.

The CNPq (Conselho Nacional de Desenvolvimento Científico e Tecnológico) is thanked for a research grant to MESC (Processo 311706/2012-6) and for financial support for the collecting trips (Sisbiota Processo 39506/ 2013-1 and INCT-Herbário Virtual Processo 563342/ 2010-2). The Stichting Hugo de Vries-fonds is thanked for travel support to AA. Leo Spier is thanked for performing thin-layer chromatography.

\section{REFERENCES}

Aptroot, A. \& Cáceres, M. E. S. (2014) A revised species concept in the tropical microlichen genus Polymeridium (Trypetheliaceae) doubles the number of known species, with a world key to species. Nova Hedwigia 98: 1-29.

Aptroot, A. \& Cáceres, M. E. S. (2016) New Trypetheliaceae from the Amazon basin in Rondônia (Brazil), the centre of diversity of the genus Astrothelium. Lichenologist 48: 693-712.

Aptroot, A. \& Lücking, R. (2016) A revisionary synopsis of the Trypetheliaceae (Ascomycota: Trypetheliales). Lichenologist 48: 763-982.

Aptroot, A., Menezes, A. A., Lima, E. L., Xavier-Leite, A. B. \& Cáceres, M. E. S. (2013) New species of Polymeridium from Brazil expand the range of known morphological variation within the genus. Lichenologist 45: 545-552.

Cáceres, M. E. S. (2007) Corticolous crustose and microfoliose lichens of northeastern Brazil. Libri Botanici 22: 1-168.

Cáceres, M. E. S., Lima, E. L., Aptroot, A. \& Lücking, R. (2014) Liquens brasileiros: novas descobertas evidenciam a riqueza no Norte e Nordeste do país. Boletim do Museu de Biologia Mello Leitão 35: 101-119.

Collinson, A. S. (1977) Introduction to World Vegetation. London: George Allen \& Unwin.

Harris, R. C. (1986, “1984”) The family Trypetheliaceae (Loculoascomycetes: lichenized Melanommatales) in Amazonian Brazil. Acta Amazonica (Supplement 1-2) 14: 55-80.

Myers, N., Mittermeier, R. A., Mittermeier, C. G., Fonseca, G. B. \& Kent, J. (2000) Biodiversity hotspots for conservation priorities. Nature 403: 853-858.

Nelsen, M. P., Lücking, R., Aptroot, A., Andrew, C. J., Cáceres, M. E. S., Rivas Plata, E., Gueidan, C., da Silva Cañez, L., Knight, A., Ludwig, L. R., et al. (2014) Elucidating phylogenetic relationships and genus-level classification within the fungal family Trypetheliaceae (Dothideomycetes: Ascomycota). Taxon 63: 974-992.

Orange, A., James, P. W. \& White, F. J. (2001) Microchemical Methods for the Identification of Lichens. London: British Lichen Society.

Thomas, W. W. (ed.) (2008) The Atlantic coastal forest of northeastern Brazil. Memoirs of the New York Botanical Garden 100: 1-586. 